\section{Prevalence and spatial distribution of intestinal parasitic infections in a rural Amazonian settlement, Acre State, Brazil}

\author{
Prevalência e distribuição espacial de parasitoses \\ intestinais em assentamento agrícola na Amazônia \\ rural, Acre, Brasil
}

Estéfano Alves de Souza 1 Mônica da Silva-Nunes 1 Rosely dos Santos Malafronte 2 Pascoal Torres Muniz 3 Marly Augusto Cardoso 4 Marcelo Urbano Ferreira 1

\section{Introduction}

A population-based survey of the prevalence and spatial distribution of intestinal parasitism was carried out in an agricultural settlement in the Amazon Basin of Brazil (Granada, Acre State). More than half (53.4\%) of the 429 stool specimens from subjects in all age groups, living in 113 households, had cysts, ova, or larvae of intestinal parasites. The most prevalent parasites were Giardia duodenalis (19.6\%) and soil-transmitted helminths (12.7\%); 105 (24.5\%) subjects were infected with more than one species of parasite. Significant age-related differences in prevalence were only found for $\mathrm{G}$. duodenalis (children $<1$ year and adults $>30$ years were less affected). Six households (5.3\%), situated within a radius of $690 \mathrm{~m}$, comprised $48.1 \%$ of all subjects harboring soil-transmitted helminths in our study area. Households within this cluster were poorer and more crowded than those outside the cluster. The observed spatial clustering of infections with soil-transmitted helminths provides valuable information for the spatial targeting of sanitary interventions in this area.

Helminths; Parasites; Amazonian Ecosystem
Intestinal parasites are estimated to infect more than three billion people worldwide 1 . Most intestinal parasites are heterogeneously distributed in host populations; according to a frequently quoted estimate, $10 \%$ of hosts harbor $70 \%$ of the intestinal helminths 2 . Specific groups at increased risk of intestinal parasitic infections represent ideal targets of public health interventions. Chemotherapy-based programs to control intestinal nematodes, for example, usually target schoolchildren, who are often at increased risk of both infection and significant morbidity 3 .

Despite the widely recognized role of environmental determinants of intestinal parasitism, the impact of interventions such as improved water supply and increased availability of latrine facilities has attracted relatively little attention 4 . The design and evaluation of large-scale sanitation interventions require appropriate spatial analysis of epidemiological data, since their targets are high-risk geographic units instead of high-risk individuals. Therefore, the study of the spatial distribution of intestinal parasitic infections can facilitate identification of modifiable factors that could be addressed by suitable interventions, or at least guide public health policies to appropriate interventions. Such an example is provided by a recent study of risk factors and spatial patterns of hookworm infection in a rural area in Côte d'Ivoire, where spatial analysis was 
used to determine the importance of local conditions versus well-established epidemiological risk factors 5 .

In Brazil, there are still some remote areas in which living conditions related to the environment are an important aspect of public health, such as rural areas in the North and Northeast regions. The epidemiology of intestinal parasitism in rural Amazonian populations has received little attention to date. A recent study performed in the State of Amazonas described intestinal parasite prevalence in subjects living in Eirunepé, along the Juruá river, but no risk factors were assessed 6 . Santos et al. 7 studied children living in a rural settlement in Minas Gerais, and the majority of them had some kind of intestinal parasite. Two recent surveys have examined putative environmental risk factors for parasitic infection in Northwest 8 and Northeast ${ }^{9}$ Brazil, indicating that living conditions can be associated with intestinal parasitism. However, the spatial distribution of infections has not been described.

This article describes the results of a population-based prevalence survey of intestinal parasites in an agricultural settlement in the Amazon Basin in Brazil. We examined the prevalence and spatial distribution of parasitic infections and investigated putative determinants of the observed clustering pattern.

\section{Subjects and methods}

\section{Study design and methodology}

A large cohort study was established in 2004 in the rural area of Acrelândia, Acre, in the western Brazilian Amazon, aiming to investigate the epidemiology and transmission dynamics of several infectious and non-infectious diseases of importance to the Amazon. The site, called Granada, located within the Padre Peixoto Settlement (Figure 1), was established in the mid-1980s about $100 \mathrm{~km}$ east of Rio Branco (capital of the State of Acre) and is inhabited by migrants from Southeast and South Brazil engaged in subsistence agriculture and cattle-raising, with coffee, banana, and rice as the main cash crops.

Two contiguous localities within the Granada area were chosen for the population study: Ramal do Granada and Reserva da Linha 14. They were chosen because of the population characteristics (fixed population living on self-owned small farms), economic and anthropological importance (farmland in deforested areas combining farmers and timber cutters), geographic location (easy access by road; spatial concentration of hundreds of people in a relatively small area along $16 \mathrm{~km}$ of road), and occurrence of several diseases of public health interest (malaria, arboviroses, anemia, etc.). A cross-sectional survey was performed within the cohort to study intestinal parasitic infections in March-April 2004 (rainy season). All inhabitants in the two adjacent localities were invited to participate in the study. The first locality, Ramal do Granada, comprises all dwellings $(n=100)$ situated on both sides of the last $16 \mathrm{~km}$ of the unpaved road known locally as Ramal do Granada, while the second locality (Reserva da Linha 14) comprises all dwellings ( $\mathrm{n}=14$ ) along a $3-\mathrm{km}$ secondary road, perpendicular to Ramal do Granada. The distribution of households in the study area $9^{\circ} 41^{\prime}-9^{\circ} 49^{\prime} \mathrm{S}$, $67^{\circ} 05^{\prime}-67^{\circ} 07^{\prime} \mathrm{W}$ can be represented as an inverted $\mathrm{L}$

The census performed by our field team in March-April 2004 identified 473 inhabitants, ranging in age from 1 day to 90 years, living in 114 dwellings across the study area. After signed informed consent had been obtained, a demographic, socioeconomic, and morbidity questionnaire was applied to 467 (98.7\%) inhabitants in the study area (or their parents or guardians) living in 113 households. The location and altitude of all households were determined using a hand-held eTrex global positioning system (Garmin International, Olathe, USA), which gives a positional accuracy within $15 \mathrm{~m}$. The survey was designed to study several diseases that are common in the Amazon, and some results on prevalence of malaria and arthropode-borne virus infection in the study population have been published elsewhere 10. The current article provides the results for intestinal parasits.

When first contacted, all subjects were given plastic containers containing $10 \%$ formalin and asked to provide a stool sample at the next visit. Formalin was added for preservation of stools due to climatic (hot and humid weather), socioeconomic (lack of refrigerators in many households), and logistic reasons (intervals between field visits). At the subsequent scheduled visits, the plastic containers were collected and sent to the field laboratory in the nearby town of Acrelândia. One to three additional visits were made if the container had not been returned when scheduled. Overall, 429 subjects $(90.7 \%$ of those living in the study area) provided stool samples and comprised the study population for this article. No significant differences ( $p>0.05$ ) were detected for most demographic, socioeconomic, and environmental parameters between subjects who provided a stool sample and those of the 38 subjects who did not provide such samples, except for age distribution and access to filtered drinking water. Significantly higher pro- 


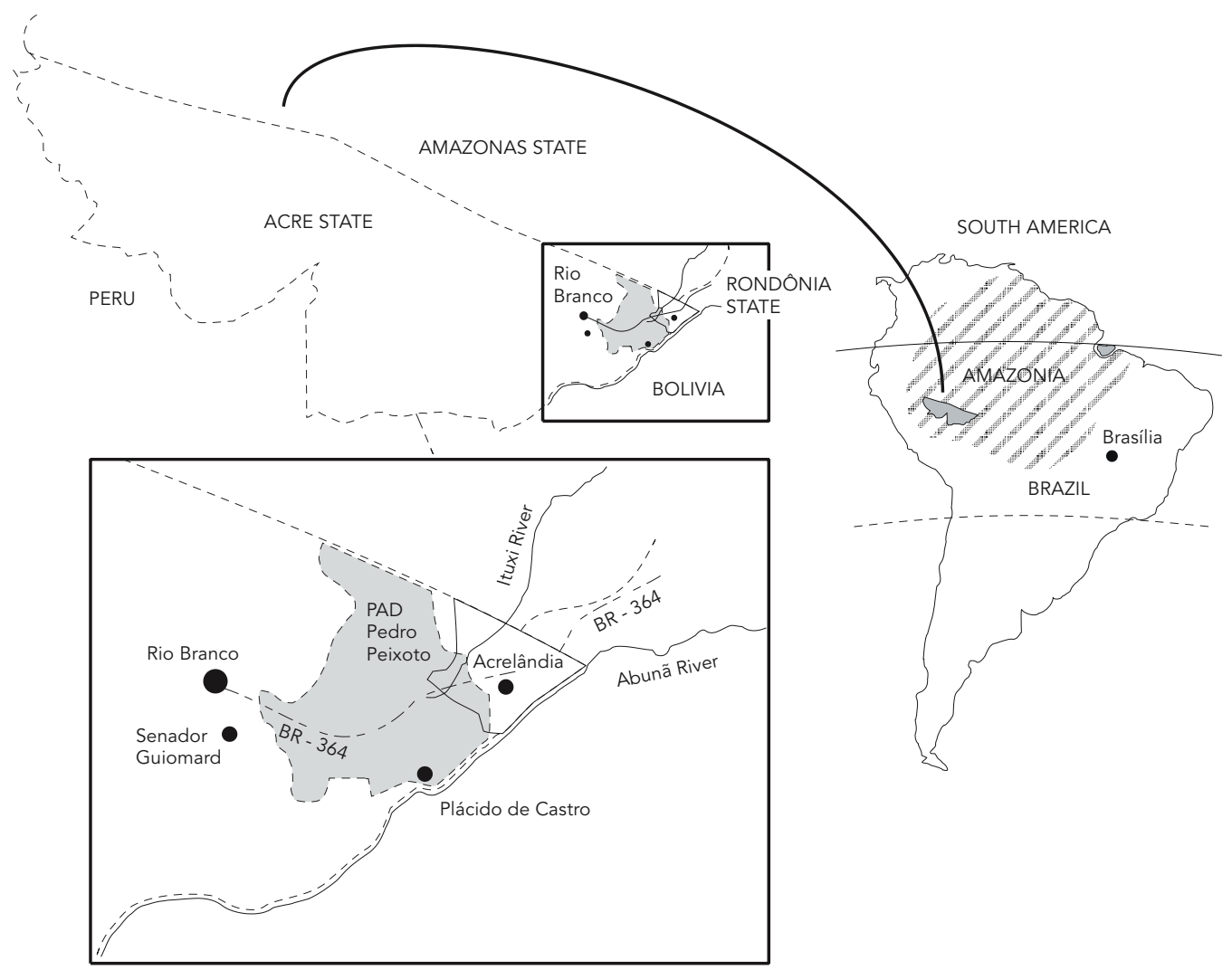

Map showing the geographic location of (a) Amazon and Brazil in South America (right side); (b) Acre in the Amazon (left upper corner); and (c) PAD Pedro Peixoto site of the population-based study (left lower corner).

portions of infants $(<1$ year of age) $(36.4 \%)$ and adolescents and young adults (aged 15-30 years) (14.8\%) failed to provide stool samples, as compared to other age groups $(0.2-6.1 \%)\left(\chi^{2}=19.05\right.$, degrees of freedom $[\mathrm{df}]=4, \mathrm{p}=0.001)$. In addition, a significantly higher proportion of subjects with access to filtered drinking water (13.2\%) failed to provide stool samples as compared to those who drank unfiltered water $(4.9 \%)\left(\chi^{2}=\right.$ 8.76 , $\mathrm{df}=1, \mathrm{p}=0.003$ ). To prevent sampling bias in prevalence estimates, we calculated adjusted prevalence rates by using the census population as a reference. However, since the adjusted and unadjusted prevalence rates were nearly identical (data not shown), only unadjusted prevalence rates are presented here.

Stool specimens were examined for parasite eggs, cysts, and larvae according to the sedimentation method described by Lutz (1919) 11 and Hoffman et al. (1934) 12. This method was preferred over the Kato-Katz method because it would allow diagnosing both helminths and protozoa (both locally prevalent infection, according to Acrelândia health authorities). Logistic limitations prevented the collection of more than one stool sample from each subject. Since variable volumes of feces were mixed with formalin for preservation, no attempt was made to perform egg or cyst counts. Infected individuals were given free treatment, provided by our field physicians: mebendazole for infections with intestinal nematodes other than Strongyloides stercoralis, albendazole for those with tapeworms, thiabendazole for those with S. stercoralis, and metronidazole for those with Giardia duodenalis or Entamoeba histolytica/E. dispar 13. 


\section{Statistical analysis}

Information on household assets was used to derive a wealth index, as described by Filmer \& Pritchett 14. Principal component analysis was used to define the household asset weights. Ownership of the following assets was investigated: TV set $(65.5 \%$ of households had one or more), stereo set $(61.1 \%)$, videotape player/recorder $(3.5 \%)$, gas stove $(88.5 \%)$, refrigerator $(74.3 \%)$, radio $(70.8 \%)$, blender $(63.7 \%)$, bicycle $(61.1 \%)$, electric iron $(54 \%)$, motor vehicle (car or motorcycle, $44.2 \%$ ), sofa set $(30.1 \%)$, washing machine $(57.5 \%)$, and parabolic antenna $(61.1 \%)$. The first principal component explained $34.5 \%$ of the variability and allocated the greatest weight to ownership of a refrigerator (0.843), television set (0.773), and parabolic antenna (0.767). Principal component analysis was carried out using the XLSTAT software, version 7.5.2 (Addinsoft, New York, USA). After standardization of these weighted asset variables 14 , the highest scores were given to ownership of a videotape player/recorder (4.820), sofa set (3.000), and motor vehicle (1.127). Lowest scores were given to households without a gas stove (-2.857), refrigerator (-1.703), and TV set (-1.378). Asset scores were summed to a wealth index for each household.

Prevalence data are presented as proportions and compared with $\chi^{2}$ or $\chi^{2}$ tests for linear trend. Means of variables with non-Gaussian distribution were compared with the Mann-Whitney test. Statistical significance was set at $5 \%$.

The Kulldorff spatial scan statistic was used to test whether intestinal parasitic infections were randomly distributed within the study area, and if not, to identify significant spatial clusters 15 . Analysis was performed using the Bernoulli model implemented in version 4.0.3 of the SaTScan software (http:/ / www.satscan.org). This program creates circular windows that are moved systematically throughout the geographic space to identify significant clusters of infections. The windows are centered on each of the households; the maximum window size, to be specified by the user, was defined here as $50 \%$ of the households (i.e., the largest possible cluster would encompass $50 \%$ of the households). For each location and size of the scanning window, SaTScan performs a likelihood ratio test to evaluate whether infection is more prevalent inside than outside that given circular window. Separate analyses were performed for: (1) infection with any intestinal parasite, (2) infection with soil-transmitted helminths, and (3) infection with G. duodenalis. P values were determined by Monte Carlo replications of the data set; a 5\% significance level was adopted.

\section{Ethical considerations}

The study protocol was analyzed and approved by the Institutional Review Board of the Instituto de Ciências Biomédicas, Universidade de São Paulo (review n. 318/CEP of July 19, 2002, and n. $538 /$ CEP of January 7,2004 ).

\section{Results}

\section{Household characteristics and prevalence of intestinal parasitic infections}

Some household characteristics were relatively homogeneous in the study area; most dwellings had electricity $(78.8 \%)$ and a latrine $(77.9 \%)$. Private wells were the main source of water for $92.9 \%$ of households; garbage was usually burned $(66.4 \%)$ or left out in the open air $(29.2 \%)$. The average number of inhabitants per room was 1.1 (range: 0.2-5.5).

Parasite cysts, eggs, or larvae were identified in 229 (53.4\%) of the 429 stool specimens examined (Table 1). Infection with soil-transmitted helminths (i.e., Ascaris, Trichuris, hookworm, or Strongyloides) was found in 54 (12.7\%) subjects. One in five subjects were infected with more than one species of parasite; one subject harbored six species; other multiple infections comprised two ( $n=79)$, three $(n=22)$, or four $(n=3)$ species. The most frequent species combinations were: (1) E. coli and Endolimax nana (10.7\% of the subjects examined), (2) G. duodenalis and Escherichia coli (6.5\%), (3) G. duodenalis and En. nana (3.5\%), (4) Ascaris lumbricoides and hookworms (1.9\%), and (5) A. lumbricoides and Trichuris trichiura (1.9\%).

Similar proportions of males and females harbored parasites, soil-transmitted helminths, and G. duodenalis ( $\mathrm{p}>0.05$ in all comparisons ( $\chi^{2}$ test). Intestinal parasitism tended to be less prevalent among children under 1 year of age, thereafter reaching a prevalence plateau around $50 \%$, but these age-related differences did not reach statistical significance. Significant age-related differences in prevalence were only found for $G$. duodenalis ( $\mathrm{p}=0.02, \chi^{2}$ test); infants $(<1$ year) and adults $>30$ years of age were relatively less affected (Figure 1).

Spatial clustering of intestinal parasitic infections

Complete data for spatial analysis were available for 426 subjects in 113 households. Spatial scan statistics revealed a single significant cluster ( $p=0.001)$ comprising 147 cases of intestinal par- 
Proportions of positive stool samples for various intestinal parasites in a rural population in the Brazilian Amazon, 2004.

\begin{tabular}{|c|c|c|}
\hline \multirow[b]{2}{*}{ Species } & \multicolumn{2}{|c|}{ Positive samples } \\
\hline & $\mathbf{n}$ & $\%$ \\
\hline \multicolumn{3}{|l|}{ Protozoa } \\
\hline Entamoeba coli & 108 & 25.2 \\
\hline Giardia duodenalis & 84 & 19.6 \\
\hline Endolimax nana & 84 & 19.6 \\
\hline lodoamoeba bütschlii & 4 & 0.9 \\
\hline Chilomastix mesnili & 3 & 0.7 \\
\hline Entamoeba histolytica/E. dispar & 2 & 0.5 \\
\hline \multicolumn{3}{|l|}{ Helminths } \\
\hline Hookworms & 33 & 7.7 \\
\hline Ascaris lumbricoides & 25 & 5.8 \\
\hline Strongyloides stercoralis & 11 & 2.6 \\
\hline Trichuris trichiura & 10 & 2.3 \\
\hline Enterobius vermicularis & 3 & 0.7 \\
\hline Hymenolepis nana & 2 & 0.5 \\
\hline
\end{tabular}

asitism (vs. 111.4 expected). Therefore, $64.8 \%$ of all subjects harboring intestinal parasites in our study area lived in 51 households (45.1\%) inhabited by 209 people $(49.1 \%$ of the study population). These households were situated within a radius of $6.9 \mathrm{~km}$.

A smaller cluster, involving 26 cases (vs. 4.8 expected) of infection with soil-transmitted helminths, was also highly significant $(p=0.001)$. Six households (5.3\%), inhabited by 38 people $(8.9 \%$ of the study population), comprised $48.1 \%$ of all subjects harboring soil-transmitted helminths in our study area. All of them were situated within a $690 \mathrm{~m}$ radius and had been included in the larger cluster of intestinal parasitism. No significant spatial clustering of G. duodenalis infection was detected.

The characteristics of households within a spatial cluster and those of households outside a cluster may be compared to provide insights into environmental determinants of intestinal parasitism. Households within the large cluster of intestinal parasitic infections were less likely to have access to filtered drinking water ( $\mathrm{p}<$ $0.00001)$ and latrines $(p=0.017)$ and had lower wealth indexes ( -2.70 vs. $1.62, \mathrm{p}=0.001$, MannWhitney test) than those outside the cluster. In addition, heads of households within the cluster had significantly fewer years of formal schooling $(p=0.049)$. Households within the smaller cluster of infections with soil-transmitted helminths had lower wealth indexes ( -13.70 vs. $0.42, p=0.0002$, Mann-Whitney test) and more inhabitants per room (2.15 vs. $1.05, \mathrm{p}=0.008$, Mann-Whitney test) as compared to those outside the cluster. However, other comparisons did not reach statistical significance, given the small number of households within this cluster. No significant difference between households inside and outside either cluster was found for any of the following characteristics: land tenure, type of material used in flooring and walls, water source, sewage elimination, and garbage disposal.

\section{Discussion}

Prevalence estimates derived from the examination of a single stool sample have been considered accurate for most intestinal parasites 16 . However, our estimates for Giardia should be interpreted with caution, since due to the intermittent elimination of cysts, examination of a single sample may underestimate the prevalence of this species. The analysis of three serial stool specimens collected on alternate days has been reported 17 to increase the detection rate of Giardia cysts by about $11 \%$. Therefore, Giardia prevalence could be even higher than reported here and can be a serious health problem in children, leading to protein-energy malnutrition 18 .

Recent use of anti-helminthic drugs, reported by nearly-one third of our study subjects, could account at least partially for the low prevalence of helminth infections in this and other rural Amazonian settings 19 . Intestinal parasitism seems 
to remain highly prevalent, in contrast, in more remote Amazonian communities, with little access to health care and medications 6,8 . However, in our population no significant association was found between reported use of anti-helminthic drugs in the previous six months and prevalence of soil-transmitted helminths (data not shown).

Large-scale programs for controlling soiltransmitted nematode infections tend to focus predominantly on chemotherapy 3 . However, environmental interventions such as improved excreta disposal seem to be a similarly efficient public health measure with greater long-term sustainability 20 and can act as a risk modifier, since poor sanitary conditions have been associated with intestinal parasites in human settlements 21 . One of the main features of environmental interventions such as those used to control vector-borne diseases 22 is their focus on geographic units (dwellings, neighborhoods, localities, villages) instead of individuals. The clustering of $48.1 \%$ of all helminth infections in $5.3 \%$ of the households is clearly relevant for the appropriate spatial targeting of sanitary interventions in our study area. Interestingly, the classical approach - chemotherapy focused on schoolchildren - is unlikely to have a major impact on the overall prevalence of soil-transmitted helminth infections in this context, since schoolchildren are not a high-risk group in our area (Figure 2).

In conclusion, analyses of spatial clustering patterns and their associated risk factors may provide valuable information to select cost-effective and sustainable measures for controlling intestinal parasitism and guide the spatial targeting of these interventions in different epidemiological settings.

Figure 2

Prevalence of infection by intestinal parasites by age. Prevalence of infection by Giardia duodenalis, soil-transmitted helminths, and any parasite according to age. Significant age-related differences in prevalence were only found for Giardia duodenalis; children $<1 \mathrm{y}$ and adults $>30 \mathrm{y}$ were less affected.

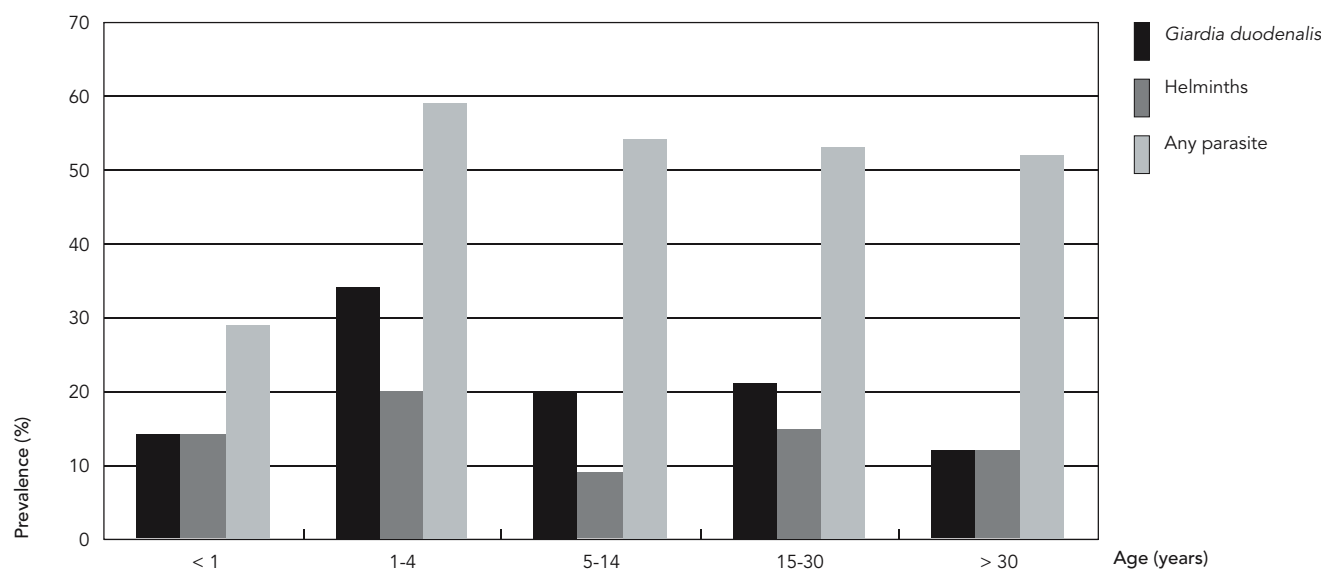




\section{Resumo}

Estudo de base populacional sobre a prevalência e distribuição de parasitoses intestinais foi realizado em assentamento agrícola na Amazônia Brasileira (Granada, Acre). Mais da metade (53,4\%) das 429 amostras analisadas de indivíduos de todas as idades, moradores de 113 domicílios, continha cistos, ovos ou larvas de parasitas intestinais. Os parasitas intestinais de maior prevalência foram Giardia duodenalis (19,6\%) e os geo-helmintos (12,7\%); 105 (24,5\%) indivíduos apresentavam co-infecção por mais de uma espécie de parasita. Houve diferença significativa em relação à idade na prevalência somente de G. duodenalis (crianças $<1$ ano e adultos $>30$ anos foram menos afetados). Seis domicílios (5,3\%), localizados num raio de $690 \mathrm{~m}$, concentraram 48,1\% de todos os indivíduos infectados por geo-helmintos na área de estudo. Domicílios incluídos nesse agregado (cluster) eram mais pobres $e$ com maior número de habitantes do que os domicílios localizados fora do agregado. A distribuição espacial dos agregados de casos de infecção por geo-helmintos fornece informações valiosas para intervenções sanitárias na comunidade da área de estudo.

Helmintos; Parasitos; Ecossistema Amazônico

\section{Contributors}

M. Da Silva-Nunes, P. T. Muniz, M. A. Cardoso, and M. U. Ferreira designed the study; M. da Silva-Nunes, R. S. Malafronte, and M. U. Ferreira performed the fieldwork; E. A. Souza created and checked the database and performed the statistical analysis; P. T. Muniz, M. A. Cardoso, and M. U. Ferreira supervised the data interpretation and statistical analysis; and M. U. Ferreira wrote the article, which was read and approved by all the authors.

\section{Acknowledgements}

We wish to thank Sebastião Bocalom Rodrigues (Mayor of Acrelândia) and Damaris de Oliveira and Nésio Mendes de Carvalho (Department of Health and Sanitation of Acrelândia) for their overall support, Adamílson Luís de Souza for his valuable help during the fieldwork, Luís Antônio Vieira Garcia for his expert collaboration in stool examinations, and Bruna de Almeida Luz for her skilled help in the data handling. The work has been supported by the Fundação de Amparo à Pesquisa do Estado de São Paulo (FAPESP, grants 03/09719-6 and 04/00373-2) and the Conselho Nacional de Desenvolvimento Científico e Tecnológico (CNPq, grants 47.0281/2003-0 and 50.4332/2004-0) Mônica da Silva-Nunes receives a FAPESP scholarship; Estéfano A. de Souza, Marly A. Cardoso, and Marcelo U. Ferreira receive $\mathrm{CNPq}$ scholarships.

\section{References}

1. Markell EK, John DT, Krotoski WA. Markell and Voge's medical parasitology. 8th Ed. Philadelphia: WB Saunders; 1999.

2. Anderson RM, May RM. Helminth infections of humans: mathematical models, population dynamics and control. Adv Parasitol 1985; 24:1-101.

3. Albonico M, Crompton DWT, Savioli L. Control strategies for human intestinal nematode infections. Adv Parasitol 1999; 42:277-341.

4. Huttly SR. The impact of inadequate sanitary conditions on health in developing countries. World Health Stat Quart 1990; 43:118-26.

5. Raso G, Vounatsou P, Gosoniu L, Tanner M, N'Goran EK, Utzinger J. Risk factors and spatial pattern of hookworm infection among schoolchildren in a rural area of western Côte d'Ivoire. Int J Parasitol 2006; 36:201-10.

6. Araujo CF, Fernandéz CL. Prevalência de parasitoses intestinais na cidade de Eirunepé, Amazonas. Rev Soc Bras Med Trop 2005; 38:69.

7. Santos MA, Rezende EG, Lamounier JA, Galvão MAM, Bonomo E, Leite RC. Hipovitaminose A em escolares da zona rural de Minas Gerais. Rev Nutr 2005; 18:331-9.

8. Eve E, Ferraz E, Thatcher VE. Parasitic infections in villagers from three districts of the Brazilian Amazon. Ann Trop Med Parasitol 1998; 92:79-87.
9. Fontbonne A, Freese-de-Carvalho E, Acioli MD, Sá GA, Cesse EAP. Fatores de risco para poliparasitismo intestinal em uma comunidade indígena de Pernambuco, Brasil. Cad Saúde Pública 2001; 17:367-73.

10. Da Silva-Nunes M, Malafronte RS, Luz BA, Souza EA, Martins LC, Rodrigues SG, et al. The Acre Project: the epidemiology of malaria and arthropodborne virus infections in a rural Amazonian population. Cad Saúde Pública 2006; 22:1325-34.

11. Lutz A. O Schistosomum mansoni e a Schistosomatose segundo observações feitas no Brazil. Mem Inst Oswaldo Cruz 1919; 11:121-55.

12. Hoffman WA, Pons JA, Janer JL. The sedimentation concentration method in schistosomiasis mansoni. Puerto Rico J Publ Health Trop Med 1934; 9: 283-91.

13. Chieffi PP, Gryschek RCB, Amato-Neto V. Parasitoses intestinais - diagnóstico e tratamento. São Paulo: Lemos Editorial; 2002.

14. Filmer D, Pritchett LH. Estimating wealth effects without expenditure data - or tears: an application to educational enrollments in states of India. Demography 2001; 38:115-32.

15. Kulldorff M, Nagarwalla N. Spatial disease clusters: detection and inference. Stat Med 1995; 14: 799-819. 
16. Gyorkos TW, McLean JD, Law CG. Absence of significant differences in intestinal parasite estimates after examination of either one or two stool specimens. Am J Epidemiol 1989; 130:976-80.

17. Garcia LS. Practical guide to diagnostic parasitology. Washington DC: ASM Press; 1999.

18. Muniz-Junqueira MI, Queiroz EFO. Relationship protein-energy malnutrition, vitamin A and parasitoses in children living in Brasília. Rev Soc Bras Med Trop 2002; 35:133-41.

19. Ferrari JO, Ferreira MU, Camargo LMA, Ferreira CS. Intestinal parasites among Karitiana Indians from Rondônia State, Brazil. Rev Inst Med Trop São Paulo 1992; 34:223-5.
20. Moraes LRS, Cancio JA, Cairncross S. Impact of drainage and sewerage on intestinal nematode infections in poor urban areas in Salvador, Brazil. Trans R Soc Trop Med Hyg 2004; 98:197-204.

21. Teixeira JC, Heller L. Fatores ambientais associados às helmintoses intestinais em áreas de assentamento subnormal, Juiz de Fora, MG. Eng Sanit Ambient 2004; 9:301-5.

22. Carter R, Mendis KN, Roberts D. Spatial targeting of interventions against malaria. Bull World Health Organ 2000; 78:1401-11.

Submitted on 12/Sep/2005

Final version resubmitted on 12/Jan/2006

Approved on 17/Jan/2006 